\title{
Portuguese science needs a shake-up
}

Sir - Adelino V. M. Canário calls for a dramatic change in the way Portuguese science is funded and managed (Nature $390,656 ; 1997)$. There is certainly a need for change, but it should be less dramatic, better organized and not based on fallacious assumptions.

His graph of gross domestic product versus number of publications in European countries is meaningless on its own. It brings to mind the study showing that high expenditure on soap in hospitals correlates very significantly with the number of deaths, which does not mean that soap consumption contributes to mortality.

Similarly, it must be remembered that 24 years ago, and after almost half a century of dictatorship, Portugal, with its $25 \%$ illiteracy level, matched standards in developing countries while in Ireland there was no illiteracy. Illiteracy has now been almost eradicated in Portugal and about $32 \%$ of secondary school students enrol in universities. So, within one generation, a revolution has occurred within the public education and research sector.

At present, these changes need to prove their usefulness for a society which is asked to finance science in the universities. It is true that academic institutions suffer from chronically low funding. However, it is also true that the lack of direct evaluation of academic staff (by students) is responsible for the frequently low quality of teaching in universities. As a result, individuals with a poor teaching record may easily reach senior tenure positions within the academic hierarchy.

Furthermore, progress in an academic career is often unrelated to scientific productivity and more or less guaranteed by a law ensuring lifelong teaching contracts, which provide little incentive to publish.

There are several bottlenecks in planning and managing research activities, but they have nothing to do with any excessive weight that undergraduate students may have in electing governing bodies at the universities. Canário confuses the issues.

In our opinion, these obstacles are mostly due to:

- lengthy evaluation of research and development project proposals at a national level (up to two years);

- delays in transferring funds to the universities for execution of projects (up to one year); - anachronistic administrative rules and an acute shortage of skilled administrative officers capable of handling the administration of research projects;

- overburdening of researchers with minor administrative duties (often as much as $80 \%$ of useful time), which transforms them into amateurish accountants.

So, before more funds are made available, as Canário asks, the administration of research at universities should be fundamentally restructured so that scientists are held accountable for the scientific results they produce rather than for their book-keeping. A strengthening of research units should provide them with the necessary basic equipment and should not be transformed into long-term funding which is quickly taken for granted. The competition for funding of research ideas between research centres is a sound system which has worked well in the past and should not be changed.

Beyond the research goals set by the European Commission in Brussels, new scientific programmes should take into greater consideration the priorities of both the national public and private sectors and include, in the case of Portugal, the once blooming but now almost abandoned research sector in Africa.

Tomasz Boski

Helena D. Galvao

UCTRA — Universidade do Algarve,

Campus de Gambelas,

8000 Faro,

Portugal

e-mail: tboski@si.ualg.pt

\section{Celebrated errors}

Sir - J. L. Heilbron and W. F. Bynum say, in their Commentary article about anniversaries of note that occur this year, that Stanley H. Cohen (Nobel prizewinner, 1986) and Herbert W. Bayer (sic) opened up the field of genetic engineering (Nature 391, 13-16; 1998).

The Stanley (no-initial) Cohen who received the Nobel prize for the discovery of epidermal growth factor is not the same as Stanley N. Cohen who laid the foundations of recombinant DNA technology along with Herbert Boyer (not Bayer), both of whom, in my view, also merit the prize.

Charles Weissmann

Institute for Molecular Biology,

Dept I, University of Zurich,

Hoenggerberg,

CH-8093 Zurich,

Switzerland

e-mail:weissma@molbio1.unizh.ch

Sir - J. L. Heilbron and W. F. Bynum mention that the US National Aeronautics and Space Administration (NASA) made history by putting into orbit three space stations called sky labs. In fact, Skylab was a single space station, launched unmanned, all up on 14 May 1973, and was visited by three successive three-man crews, the last of which departed on 8 February 1974.

On 11 July 1979, Skylab struck the Earth's surface, scattering debris from the southeastern Indian Ocean to Western Australia. Readers interested in Skylab can visit the NASA Web site (http://www.ksc. nasa.gov/history/skylab/skylab.html). Julian A. Hiscox

Division of Molecular Biology,

IAH Compton Laboratory,

Compton, Berks RG20 7NN, UK

e-mail:julian.hiscox@bbsrc.ac.uk

\section{Biology versus physics}

Sir - Your leading article "Biology versus physics" questions the existence of Kuhnian paradigms in biology (Nature 391, 107; 1998). I would offer as a candidate the demonstration by Lynn Margulis and others that mitochondria are endosymbionts descended from formerly free-living proteobacteria. For, to those of us interested in both evolution and religion, the confirmation that human and other eukaryotic cells were really bacterial cooperatives (in Whose image?) certainly felt like a double-strength paradigm shift. Arndt von Hippel 1649 Bannister Drive,

Anchorage, Alaska 99508, USA e-mail:102251.527@compuserve.com

\section{'Mad' science wanted}

Sir - Towards the end of your interview with Daedalus, he points out that even Sir Peter Medawar felt that $80 \%$ of his research activity had been completely wasted, and that this is a typical record (Nature 390, $126-127$; 1997). Perhaps his main point was that a $20 \%$-efficient activity shouldn't be taken too seriously. But can Daedalus suggest an entropy-defying device by which I can determine which of my activities belong in the $80 \%$ 'fruitless' category and trade those for exploring not-soserious, unconventional 'mad' experiments?

Boryeu Mao

Pharmacia and Upjohn Inc.,

Kalamazoo, Michigan 49001, USA

e-mail:bmao@raven.pnu.com 